\title{
IMPACT OF THE TEMPERATURE OF WASTE BIOMASS PY-ROLYSIS ON THE QUALITY OF THE OBTAINED BIOCHAR ${ }^{1}$
}

\begin{tabular}{|c|c|}
\hline \multicolumn{2}{|c|}{$\begin{array}{l}\text { Department of Fuel Technology, AGH University of Science and Technology in Krakow } \\
\text { * Corresponding author: e-mail: mmarczak@agh.edu.pl }\end{array}$} \\
\hline ARTICLE INFO & ABSTRACT \\
\hline $\begin{array}{l}\text { Article history: } \\
\text { Received: February } 2016 \\
\text { Received in the revised form: } \\
\text { March } 2016 \\
\text { Accepted: March } 2016\end{array}$ & $\begin{array}{l}\text { Combustion and co-combustion of biomass from different sources is } \\
\text { one of the most popular technologies applied in Poland. It allows } \\
\text { management of numerous industrial, communal and agricultural } \\
\text { waste. Organic waste constitutes one of the richest sources of cheap } \\
\text { biomass solid fuels since they are very popular. The paper includes an }\end{array}$ \\
\hline $\begin{array}{l}\text { Key words: } \\
\text { biomass, } \\
\text { nutshell, } \\
\text { pyrolysis, } \\
\text { calorific value }\end{array}$ & $\begin{array}{l}\text { assessment of practical use of biomass waste: hazelnut shell and } \\
\text { pistachio nut shell. The impact of pyrolysis temperature (300, } 450 \text { and } \\
\left.550^{\circ} \mathrm{C}\right) \text { of the investigated biomass on the quality of the obtained } \\
\text { biochar was determined and the optimal temperature of this process } \\
\text { was defined. The quality of the investigated biomass was analysed on } \\
\text { account of its use for energy purposes. Numerous advantageous } \\
\text { properties of the obtained materials were found out, for instance: low } \\
\text { content of ash and a noticeable increase of the calorific value with an } \\
\text { increase of the pyrolysis temperature. }\end{array}$ \\
\hline
\end{tabular}

\section{Introduction}

Energy resources have always played a significant role in the development of civilization. Thus, location of fossil fuels deposits or possibility of using alternative energy sources is for many states a key factor which decides on the economic independence. However, the last energy trends suggests that fossil fuels should be gradually replaced by solutions from the group of renewable energy sources which are less burdening for the environment. High costs of investments and specific location requirements are problems related to implementation of a new solution for obtaining energy. Biomass combustion is one of the methods, which may be used regardless the location on account of energy biomass variability and its availability (Demirbas, 2005). The biomass combustion consists in the use of existing organic waste from other industry branches such as: paper (Singh et al., 2000), wood chips (Sampson et al., 1991), sawdust and sewage (Abbas et al., 1994), proso millet (Aerts et al., 1997), straw (Denisiuk, 2006), nutshell (Rozwadowski et al., 2012) and other waste material (Abbas et al., 1994). The greatest advantage of such a solution is, inter alia, reduced emission of $\mathrm{CO}_{2}$ and practically no emission of sulphur oxide and nitrogen oxide and chem-

1 The paper was written as a part of the statute work of AGH University of Science and Technology no. 11.11.210.213. 
ical composition which has a similar quality to traditional fuels (Hein and Bemtgen, 1998; Easterly and Burnham, 1996).

The mentioned advantages are main reasons for which biomass combustion is often considered in the form of its combustion together with traditional fuels in the process of the so-called biomass co-combustion (Sami et al., 2001). Unfortunately, both combustion and co-combustion of biomass shows many problems. The first problem is related to fuel storage. Usually biomass includes more moisture, less elemental carbon and more oxygen; therefore it has a lower calorific value in comparison to fossil fuels (Wójcik and Kostrubiec, 2015; Niedziołka et al., 2014). It generates higher transport costs of biomass (Kopczyński and Zuwała, 2013) and in order to produce the same amount of energy as in case of carbon combustion its greater quantity has to be combusted (Ściążko et al., 2006).

Biomass disorders may be efficiently eliminated by previous pyrolysis as a result of which it loses a great part of moisture and volatile particles (mainly oxygen) and achieves a chemical composition similar to fossil fuels. Such type of processing enables improvement of the combustion process efficiency (Kopczyński and Zuwała, 2013a), allows reduction of fuel transport costs (Kopczyński and Zuwała, 2013b) and increases the calorific value of biomass (Berrueco et al., 2014). Detailed conditions for initial pyrolysis of biomass and impact on its fuel properties have not been recognized entirely.

The objective of the research was to determine an optimal temperature of the waste biomass pyrolysis from the point of view of desired properties of obtained biochars. Pistachio and hazelnut shells were selected for research as potentially the most attractive fuel on account of relatively low moisture content. A low temperature pyrolysis, known as torrification, was carried out in the temperatures of 300,450 and $550^{\circ} \mathrm{C}$. The scope of analysis enabled determination of the research biomass usefulness and the obtained biochars to use it as fuel for combustion and co-combustion with carbon fuels.

\section{Experimental part}

\section{Research material}

Waste organic biomass in the form of hazelnut shells and pistachio shells was selected for research. Research material was dried in room conditions for 48 hours. Then it was milled and sieved to obtain the fraction less than $0.5 \mathrm{~mm}$. The samples were subjected to isothermal pyrolysis in the temperature of 300,450 and $550^{\circ} \mathrm{C}$. Pyrolysis of samples was carried out for 30 minutes in closed ceramic vessels placed in the muffle furnace by Czylok. The prepared samples were used for further research.

\section{Methodology of research}

The used biomass and obtained biochar were subjected to elementary and technical analysis.

The elementary analysis included determination of the elemental carbon, hydrogen and sulphur content. The research was carried out with Eltra CHS-580 analyser pursuant to the laboratory procedure developed acc. to PN-G-04571 standard: 1998 and PN-G-04584. Technical analysis included determination of the moisture, ash and volatile particles content. These tests were carried out in the muffle furnace by Czylok according to the stand- 
Impact of the temperature...

ards: PN-EN ISO 18134-1:2015-11, PN-EN ISO 18134-3:2015-11 and PN-EN ISO 18123:2016-01. The heat of combustion was measured with a calorimetric method and the calorific value was calculated acc. to PN-EN 14918 standard: 2010. The iterations were within repeatability, which was determined in the standards concerning particular analyses.

In order to obtain an optimal temperature of pyrolysis, a thermogravimetric analysis was carried out on the pressure thermobalance DynTHERM by Rubotherm in the atmosphere of argon with the temperature increase of $3^{\circ} \mathrm{C} \cdot \mathrm{min}^{-1}$.

\section{Results and discussion}

\section{Results of elementary and technical analysis}

Elementary analysis proved the increase of the carbonification degree of samples with the increase of the pyrolysis temperature for both types of the investigated biomass (table 1). An elemental composition of output materials was similar. The process of their pyrolysis caused the increase of elemental carbon from less than $50 \%$ content to as much as $90 \%$ content for biochar obtained in the temperature of $550^{\circ} \mathrm{C}$. Pyrolysis caused a small decrease of the hydrogen content which may prove a considerable content of oxygen groups in the investigated biomass. The content of sulphur in the investigated biomass was very low (0.01-0.02\% content), and the process of pyrolysis caused additionally its decrease practically to zero.

Table 1.

The content of $C, H$ and $S$ elements in the investigated samples of biomass and in biochars obtained therefrom

\begin{tabular}{lccccccc}
\hline $\begin{array}{l}\text { Pistachio } \\
\text { shells }\end{array}$ & $\mathrm{C}$ & $\mathrm{H}$ & $\mathrm{S}$ & $\begin{array}{c}\text { Hazelnut } \\
\text { shells }\end{array}$ & $\mathrm{C}$ & $\mathrm{H}$ & $\mathrm{S}$ \\
\hline \multicolumn{7}{c}{ (p. by weight) } \\
$\begin{array}{l}\text { Output mate- } \\
\text { rial }\end{array}$ & $42.3 \pm 0.3$ & $5.38 \pm 0.3$ & $0.01 \pm 0.05$ & $\begin{array}{c}\text { Output } \\
\text { material }\end{array}$ & $47.6 \pm 0.3$ & $5.77 \pm 0.3$ & $0.01 \pm 0.05$ \\
\hline $\begin{array}{l}\text { Biochar } \\
300^{\circ} \mathrm{C}\end{array}$ & $62.3 \pm 0.3$ & $3.85 \pm 0.3$ & $0.01 \pm 0.05$ & $\begin{array}{c}\text { Biochar } \\
300^{\circ} \mathrm{C}\end{array}$ & $67.9 \pm 0.3$ & $4.18 \pm 0.3$ & $0.01 \pm 0.05$ \\
\hline $\begin{array}{l}\text { Biochar } \\
450^{\circ} \mathrm{C}\end{array}$ & $85.6 \pm 0.3$ & $2.56 \pm 0.3$ & $0.01 \pm 0.05$ & $\begin{array}{c}\text { Biochar } \\
450^{\circ} \mathrm{C}\end{array}$ & $76.6 \pm 0.3$ & $3.01 \pm 0.3$ & 0.00 \\
$\begin{array}{l}\text { Biochar } \\
550^{\circ} \mathrm{C}\end{array}$ & $92.5 \pm 0.3$ & $1.64 \pm 0.3$ & 0.0 & $\begin{array}{c}\text { Biochar } \\
550^{\circ} \mathrm{C}\end{array}$ & $91.4 \pm 0.3$ & $2.17 \pm 0.3$ & 0.00 \\
\hline
\end{tabular}

In biomass for energy purposes, a high content of moisture reduces its calorific value because a part of heat is lost on heating and water vapouring. Reduction of moisture content has a great impact on the quality of fuel. Figure 1 a presents the relation of the moisture content in the investigated samples to the temperature of pyrolysis. Shells of the investigated hazelnut have a considerably low content of analytical moisture (6.9-8.1) $\pm 0.2 \mathrm{p}$. by weight. Pyrolysis caused a considerable reduction of moisture content, however, not a complete drying of biomass. It may result from the conditions, in which pyrolysis was carried out, namely from closed vessels and no flow of inert gas. A higher temperature of biochar caused better drying of samples, which resulted from both temperature and longer duration of pyrolysis. 
a)

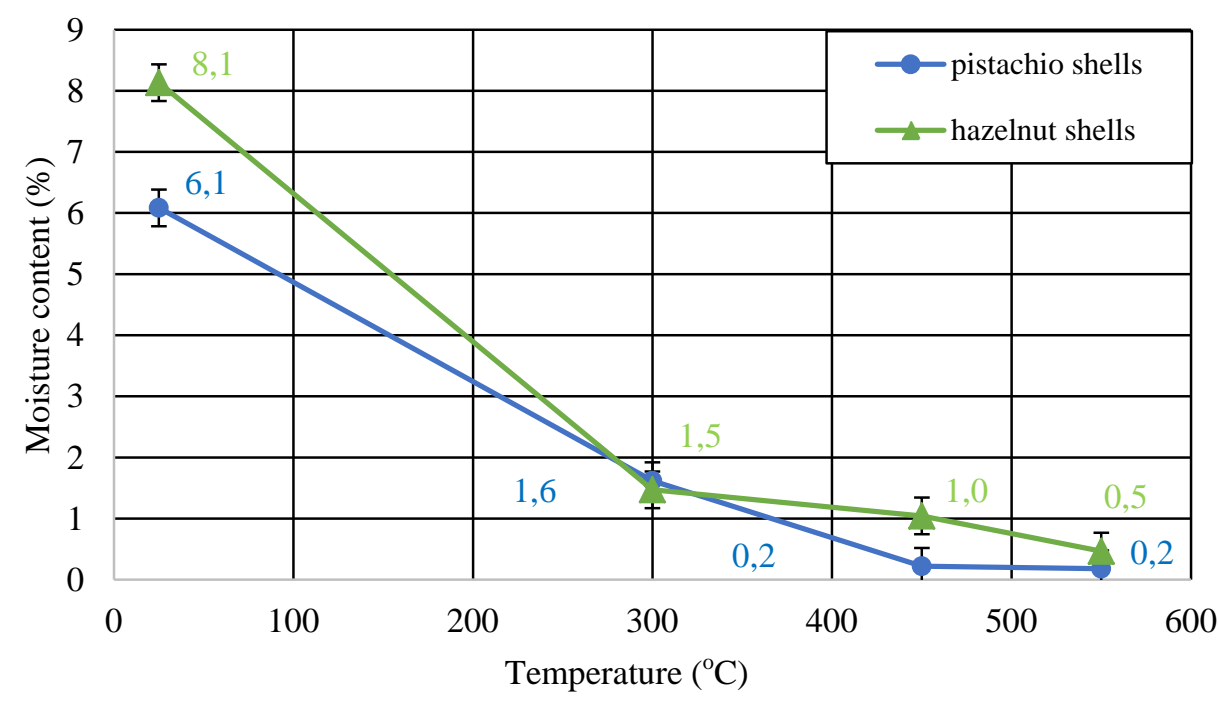

b)

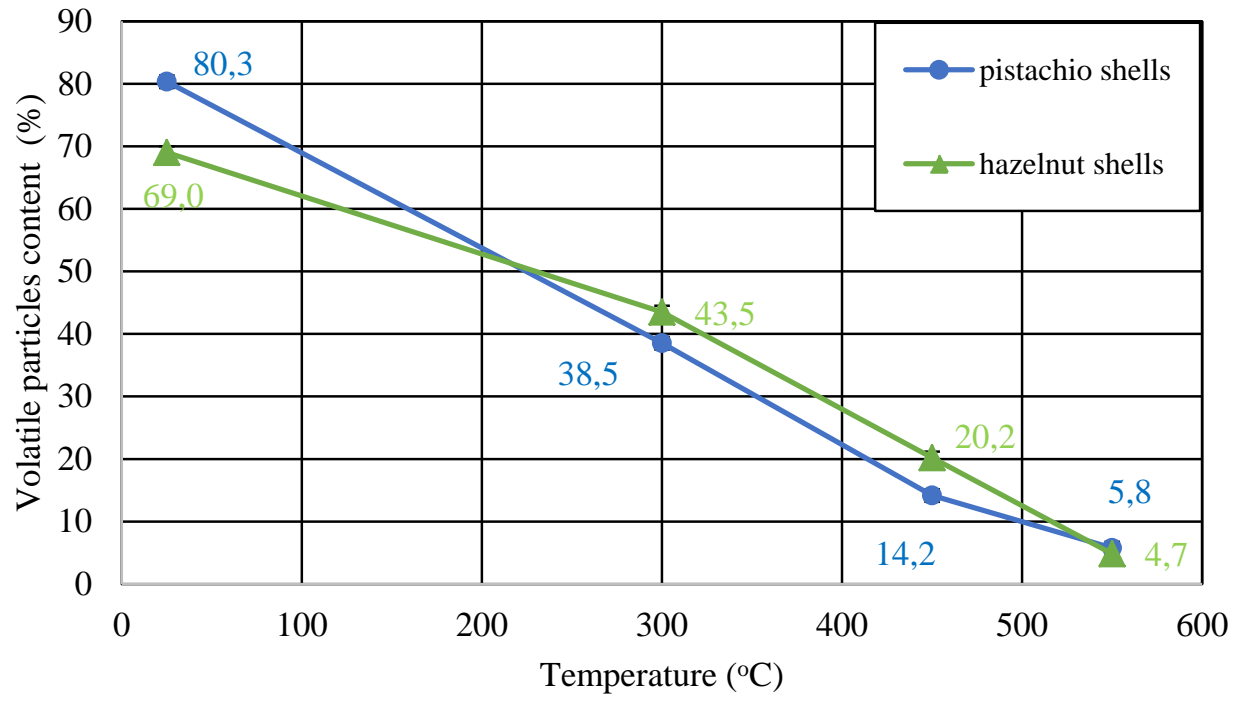


c)

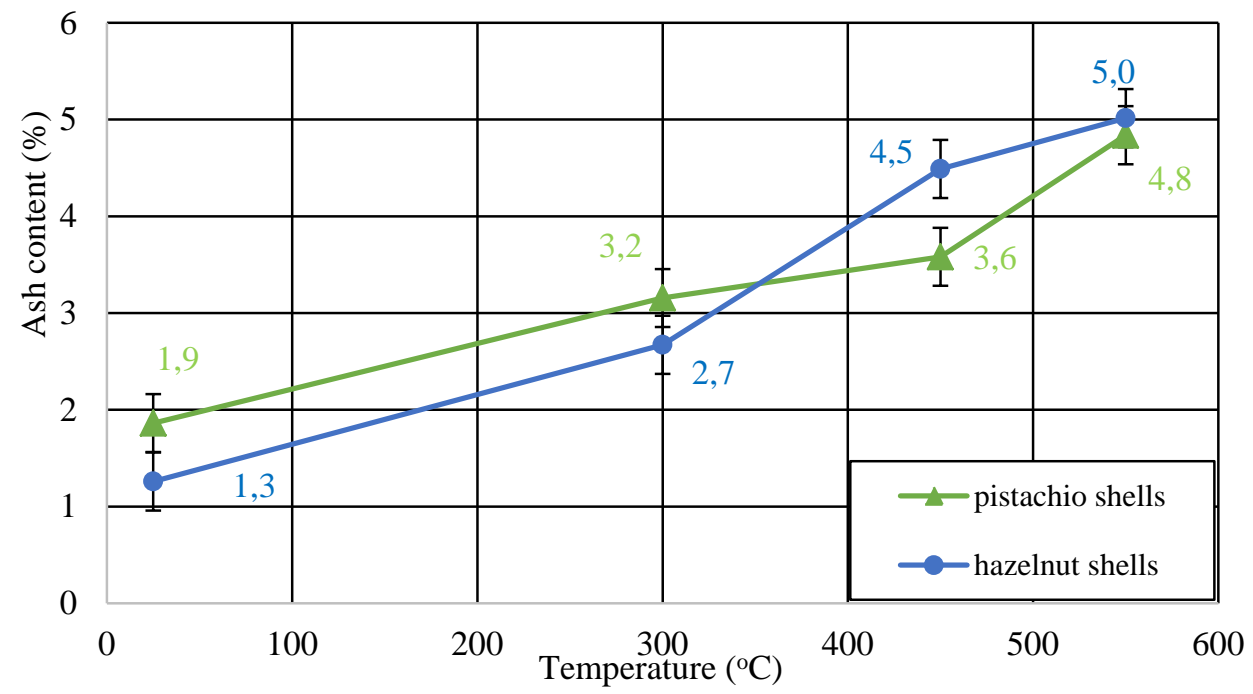

d)

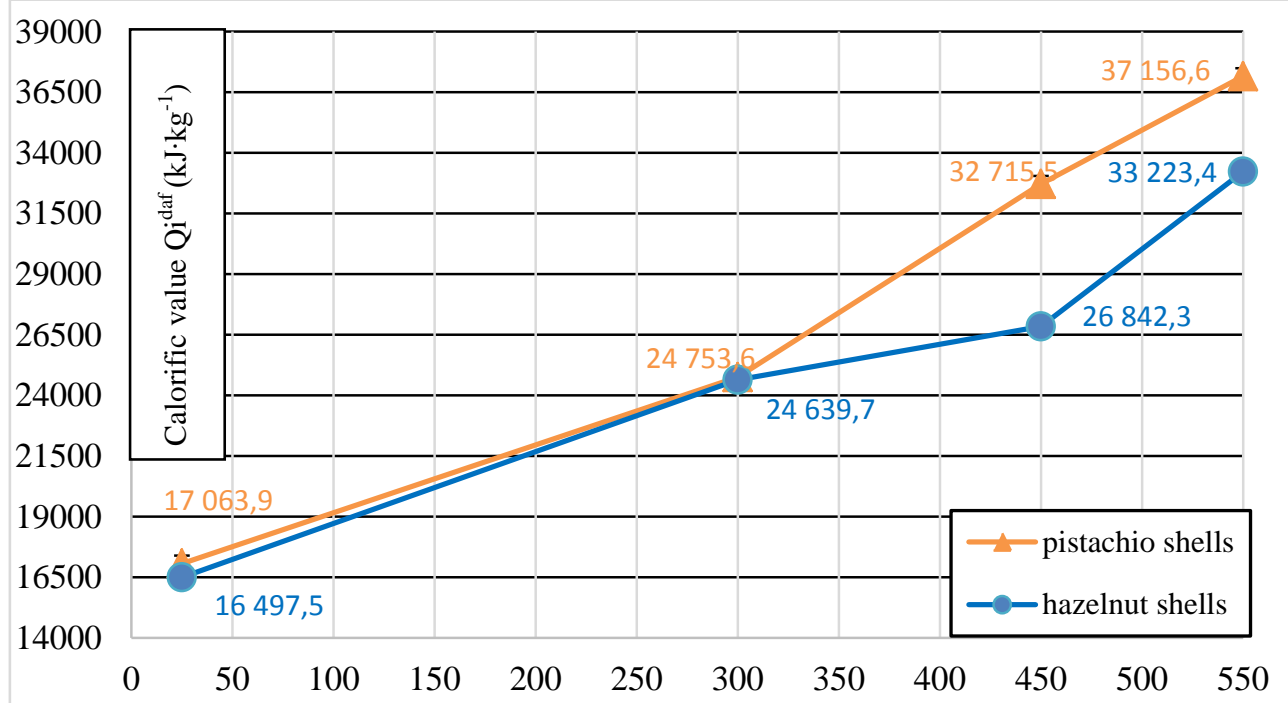

Temperature $\left({ }^{\circ} \mathrm{C}\right)$

Figure 1. Relation of the content (analytical state) ; a) of moisture, b) volatile particles c) ash and d) calorific value (dry non-ash state) in initial samples and biochars to the temperature of their pyrolysis 
Results of measurement on the content of volatile particles in the investigated biomass and biochars were presented in figure $1 \mathrm{~b}$. Both pistachio and hazelnut shells have a high content of volatile parts (respectively 69.00 and 80.33 p. by weight) The process of pyrolysis causes reduction of volatile particles and the relation of the content of volatile parts to the temperature of pyrolysis is practically linear. In case of natural solid fuels the content of volatile particles is a measure of their thermal resistance related to the degree of carbonification (metamorphism).

Based on the literature (Abbas et al., 1994; Van Doorn et al., 1996) it was found out that the content of volatile particles at the level of $15-30 \pm 0.3 \mathrm{p}$ by weight and the elemental carbon content $80-90 \pm 0.3$ by weight in the biomass results in the higher value of heat of combustion. Such content of volatile particles was obtained in biochar obtained within the temperature of pyrolysis of $300-450^{\circ} \mathrm{C}$.

A very significant element which constitutes a ballast for solid fuels is ash which they contain. The content of this component had impact on the reduction of the calorific value of solid fuel and constitutes a source of harmful elements (e.g. S, Na, K, Cl). The content of ash in the investigated samples of biomass and obtained biochar was presented in figure 1 c. Shells of the investigated hazelnut have a low content of ash (1.3 and $1.9 \pm 0.3$ by weight. As a result of pyrolysis, water vapouring and decomposition of organic substance, the content of ash increases to $5 \pm 0.3 \mathrm{p}$. by weight in biochar obtained in $550^{\circ} \mathrm{C}$.

Calorific value of initial materials is $17 \pm 0.3 \mathrm{MJ} \cdot \mathrm{kg}^{-1}$ for pistachio shells and $16.5 \pm 0.3 \mathrm{MJ} \cdot \mathrm{kg}^{-1}$ for hazelnut shells (figure $1 \mathrm{~d}$ ) and is considerably high as for waste material but noticeably worse than classical solid fuels. A higher calorific value of hazelnut shells than pistachio shells is also maintained in biochars obtained in $300^{\circ} \mathrm{C}$, where materials obtain an increase of the calorific value to respectively $24.75 \pm 0.3 \mathrm{MJ} \cdot \mathrm{kg}^{-1}$ and $24.60 \pm 0.3$ $\mathrm{MJ} \cdot \mathrm{kg}^{-1}$. However, pyrolysis in higher temperatures leads to a noticeable increase of the calorific value for pistachio shells, whose calorific value increased to $32.7 \pm 0.3 \mathrm{MJ} \cdot \mathrm{kg}^{-1}$ for $450^{\circ} \mathrm{C}$, and for $550^{\circ} \mathrm{C}$ to $37 \pm 0.3 \mathrm{MJ} \cdot \mathrm{kg}^{-1}$. For comparison in the same temperatures biochar from hazelnut shells increased its calorific value to $27 \pm 0.3 \mathrm{MJ} \cdot \mathrm{kg}^{-1}$ for $450^{\circ} \mathrm{C}$ and $33.2 \pm 0.3$ $\mathrm{MJ} \cdot \mathrm{kg}^{-1}$ for $550^{\circ} \mathrm{C}$. Differences in the calorific value result most probably from differences in the content of carbon element in the investigated samples. Moreover, it should be mentioned that the achieved values are confirmed by the results of the elementary analysis. Such high calorific value of both materials makes them a very attractive raw material for use as fuel combusted separately or co-combusted. However, one should remember that high calorific value of biochar was obtained at the expense of energy consumed by the process of pyrolysis.

To initially determine in which temperature range of pyrolysis the highest increase of energy took place, the increase of the calorific value was calculated into Celsius degrees. Thus, it was possible to find the highest increase of the calorific value at the expense of the introduced energy. Results of these calculations were presented in table 2.

The first stage of pyrolysis which consists in heating a sample from the initial state to $300^{\circ} \mathrm{C}$ gives a very similar increase of the calorific value for both types of shells. However, the next stages prove to be significant. Pyrolysis of pistachio shells within $300-450^{\circ} \mathrm{C}$ proves to give higher increase of the calorific value for each Celsius degree than the previous stage. To degas the sample above $450^{\circ} \mathrm{C}$ this increase is however noticeably lower. In case of hazelnut shells, the increase of the calorific value above the temperature of $300^{\circ} \mathrm{C}$ is considerably smaller and balancing the calorific value with pistachio shells is possible only 
Impact of the temperature...

in the highest temperature of $550^{\circ} \mathrm{C}$. It means that the best temperature of pyrolysis will be $300^{\circ} \mathrm{C}$. The process of pyrolysis for pistachio shells will be the best for the temperature of $450^{\circ} \mathrm{C}$ in order to obtain the highest calorific value in comparison to the energy consumed for heating.

Table 2.

The increase of the calorific value of biochar in comparison to the increase of the pyrolysis temperature for the analysed biomass

\begin{tabular}{|c|c|c|}
\hline \multirow{2}{*}{$\begin{array}{l}\text { The scope of pyrolysis } \\
\text { temperature }\left({ }^{\circ} \mathrm{C}\right)\end{array}$} & \multicolumn{2}{|c|}{$\begin{array}{c}\text { The increase of calorific value } \\
\left(\mathrm{kJ} \cdot \mathrm{kg}^{-1}{ }^{\circ}{ }^{\circ} \mathrm{C}^{-1}\right)\end{array}$} \\
\hline & Pistachio shells & Hazelnut shells \\
\hline Initial material - 300 & 29.0 & 29.6 \\
\hline $300-450$ & 52.7 & 14.7 \\
\hline $450-550$ & 38.2 & 63.8 \\
\hline
\end{tabular}

\section{Biochar yield}

A biochar yield was calculated as a relation of the obtained mass of biochar in a specific temperature to the output mass of biomass sample subjected to pyrolysis. Table 3 presents biochar yield in various temperatures.

Table 3.

Biochar yield from investigated materials in various temperatures of pyrolysis

\begin{tabular}{lcc}
\hline \multirow{2}{*}{ Temperature $\left({ }^{\circ} \mathrm{C}\right)$} & \multicolumn{2}{c}{ Yield (\%) } \\
\cline { 2 - 3 } & Pistachio shells & Hazelnut shells \\
\hline 300 & 43.4 & 49.8 \\
\hline 450 & 23.8 & 29.3 \\
\hline 550 & 20.1 & 23.8 \\
\hline
\end{tabular}

According to the list, the biggest losses of materials during pyrolysis occurred in the temperature of $550^{\circ} \mathrm{C}$ and were $76-80 \%$. Higher amounts were obtained from hazelnut shells (3-6\%), in comparison to biochar from pistachio shells. However, during pyrolysis even in the temperature of $300^{\circ} \mathrm{C}$ the losses exceeded $50 \%$ for both materials. The process of pyrolysis in higher temperatures requires great amounts of the input material in the form of hazelnut shells. Thus, carrying out this process in higher temperatures for this biomass seems to be aimless.

\section{Results of thermogravimetric analysis}

Figure 2 and 3 presents a thermogravimetric diagram of the investigated biomass. The thermogravimetric analysis was carried out for the output material in order to determine the temperature, where the relevant process of pyrolysis takes place for this type of biomass. The fastest mass loss took place in the temperature of $296.5^{\circ} \mathrm{C}$ for pistachio shells and $303.2^{\circ} \mathrm{C}$ hazelnut shells. In both cases a big loss in samples mass ends in the temperature of $320^{\circ} \mathrm{C}$. In higher temperatures the loss of biochar mass was much slower; therefore it may 
be assumed that the temperature of approx. $350^{\circ} \mathrm{C}$ is the optimal temperature of the pyrolysis process for this type of biomass.
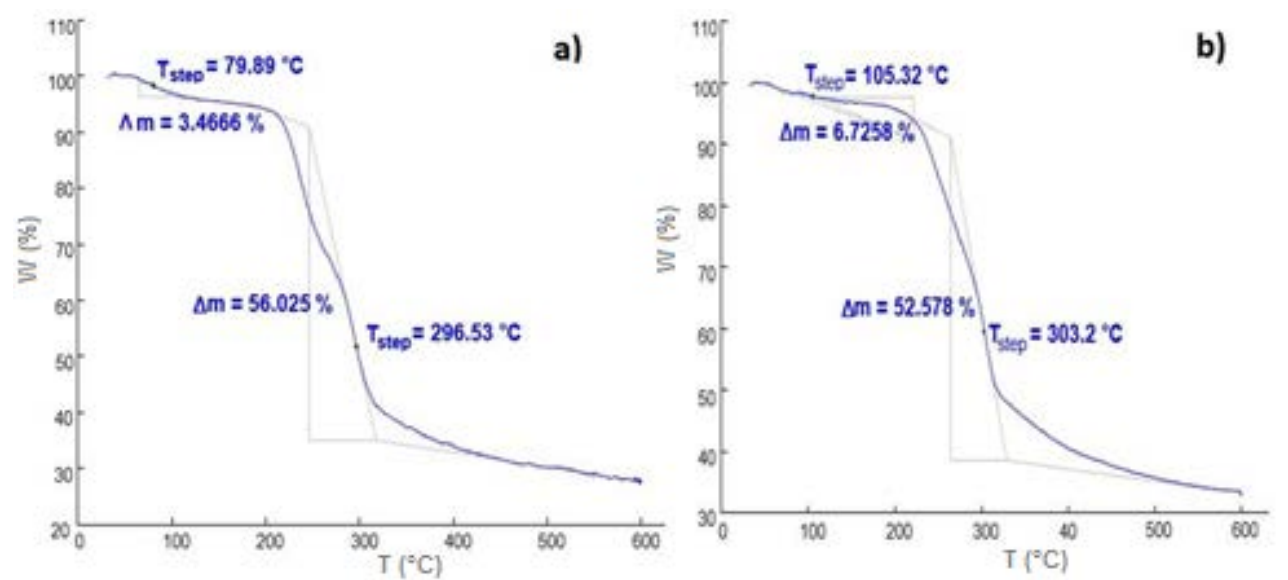

Figure 2. Thermogravimetric curves of the investigated waste biomass: a) pistachio shells; b) hazelnut shells

\section{Conclusion}

The tests which were carried out allowed determination of usefulness of biochar obtained from waste biomass for energy purposes and enabled determination of the optimal scope of the temperature of pyrolysis. On this account, the analysis of the obtained results shows that the best temperature of pyrolysis for hazelnut shells is $300^{\circ} \mathrm{C}$. In this temperature biochar with the calorific value of $25 \pm 0.3 \mathrm{MJ} \cdot \mathrm{kg}^{-1}$ was obtained. Pistachio shells show, on the other hand, a bigger increase of the calorific value in the entire scope of the selected temperatures, therefore their pyrolysis within $300-450^{\circ} \mathrm{C}$ allows obtaining biochar with a high calorific value of $33 \pm 0.3 \mathrm{MJ} \cdot \mathrm{kg}^{-1}$, making them more economic for energy purposes. Determination of optimal conditions of pyrolysis for these materials requires making careful analysis within the temperatures of $300-450^{\circ} \mathrm{C}$. However, favourable properties of these materials confirm their high potential as biomass fuel.

\section{References}

Abbas, T., Costen, P., Kandamby, N. H., Lockwood, F. C., Ou, J. J. (1994). The influence of burner injection mode on pulverized coal and biomass co-fired flames. Combustion and flame, 99(3), 617-625.

Aerts, D. J., Bryden, K. M., Hoerning, J. M., Ragland, K. W., Weiss, C. A. (1997). Co-firing switchgrass in a $50 \mathrm{MW}$ pulverized coal boiler (No. CONF-970456). Illinois Inst. of Tech., Chicago, IL (United States).

Berrueco, C., Lorente, E., Van Niekerk, D., Millan, M. (2014). Evolution of tar in coal pyrolysis in conditions relevant to moving bed gasification. Energy \& Fuels, 28(8), 4870-4876. 
Impact of the temperature...

Bryers, R. W. (1999). Factors critically affecting fireside deposits in steam generators. [W]: Gupta, R., Wall T., Baxter L. (red.), Impact of Mineral Impurities in Solid Fuel Combustion (105-131) New York, Kluwer Academic/ Plenum Publishers.

Demirbas, A. (2005). Potential applications of renewable energy sources, biomass combustion problems in boiler power systems and combustion related environmental issues. Progress in Energy and Combustion Science, 31, 171-192.

Denisiuk, W. (2006). Produkcja roślinna jako źródło surowców energetycznych. Agricultural Engineering, 5, 123-131.

Easterly, J. L., \& Burnham, M. (1996). Overview of biomass and waste fuel resources for power production. Biomass and Bioenergy, 10(2), 79-92.

Hein, K. R. G., Bemtgen, J. M. (1998). EU clean coal technology-co-combustion of coal and biomass. Fuel Processing Technology, 54(1), 159-169.

Kopczyński, M., Zuwała, J. (2013a). Biomasa toryfikowana - nowe paliwo dla energetyki. Chemik, 67(6), 540-551.

Kopczyński, M., Zuwała, J. (2013b). Toryfikacja biomasy droga do eliminacji barier technologicznych wielkoskalowego jej współspalania. Polityka Energetyczna, 16(4), 271-284.

Niedziółka, I., Szpryngiel, M., Zaklika, B. (2014). Possibilities of using biomass for energy purposes Agricultural Engineering, 149(1), 155-163.

Ohlsson, O. (1994). Results of combustion and emissions testing when co-firing blends of binderenhanced densified refuse-derived fuel (b-dRDF) pellets and coal in a $440 \mathrm{MW}$ \{sub e cyclone fired combustor. Volume 2: Field data and laboratory analysis. Obtained from: http://www.nrel.gov/docs/legosti/old/6322b.pdf

PN-EN ISO 18134-3:2015-11. Biopaliwa stałe - Oznaczanie zawartości wilgoci -Metoda suszarkowa - Część 3: Wilgoć w próbce do analizy ogólnej.

PN-EN ISO 18123:2016-01. Biopaliwa stałe - Oznaczanie zawartości części lotnych.

PN-EN ISO 18122:2016-01. Biopaliwa stałe - Oznaczanie zawartości popiołu.

PN-EN 14918:2010. Biopaliwa stałe - Oznaczanie wartości opałowej.

Rozwadowski, A., Rozwadowska, T., Kuliga, J. (2012). Temperatura zapłonu i inne właściwości energetyczne karbonizatów z wybranych rodzajów biomasy i węgla kamiennego. Energetyka, 7, 400-404.

Sampson, G. R., Richmond, A. P., Brewster, G. A., Gasbarro, A. F. (1991). Cofiring of wood chips with coal in interior Alaska. Forest products journal, 41(5), 53-56.

Sami, M., Annamalai, K., Wooldridge, M. (2001). Co-firing of coal and biomass fuel blends. Progress in energy and combustion science, 27(2), 171-214.

Singh, B. P., Panigrahi, M. R., Ray, H. S. (2000). Review of biomass as a source of energy for India Energy Sources, 22(7), 649-658.

Ściążko, M., Zuwała, J., Pronobis, M. (2006). Zalety i wady współspalania biomasy w kotłach energetycznych na tle doświadczeń eksploatacyjnych pierwszego roku współspalania biomasy na skalę przemysłową. Energetyka, 5, 207-220.

Wójcik, G., Kostrubiec, M. (2015). Impact of plant biomass moisture on efficiency, unit energy consumption and quality of pellet. Agricultural Engineering, 3(155), 149-156.

Van Doorn, J. (1997). Combined combustion of biomass, municipal sewage sludge and coal in an atmospheric fluidized bed installation. Fuel and Energy Abstracts, 38(6), 420-421. 


\section{WPLYW TEMPERATURY PIROLIZY BIOMASY ODPADOWEJ NA JAKOŚĆ UZYSKANYCH KARBONIZATÓW}

Streszczenie. Spalanie i współspalanie biomasy różnego pochodzenia to jedno z najczęściej stosowanych technologii w Polsce, które pozwala na zagospodarowanie licznych odpadów przemysłowych, komunalnych i rolniczych. Odpady organiczne ze względu na powszechne występowanie stanowią jedno z najbogatszych źródeł tanich biomasowych paliw stałych. W pracy dokonano oceny praktycznego wykorzystania odpadów biomasowych: łupin orzecha laskowego oraz pistacji. Zbadano wpływ temperatury $\left(300,450\right.$ i $\left.550^{\circ} \mathrm{C}\right)$ pirolizy badanej biomasy na jakość uzyskanych karbonizatów oraz określono optymalną temperaturę tego procesu. Jakość badanej biomasy analizowano pod kątem wykorzystania jej do celów energetycznych. Stwierdzono szereg korzystnych właściwości otrzymywanych materiałów, takich jak: niska zawartość popiołu i zauważalne zwiększenie wartości opałowej wraz ze wzrostem temperatury pirolizy.

Słowa kluczowe: biomasa, łupiny orzechów, piroliza, wartość opałowa 